\title{
Adaptation and validation of the Melbourne Decision Making Questionnaire to Brazilian Portuguese
}

\author{
Adaptação e validação do Melbourne Decision Making Questionnaire em \\ português brasileiro
}

Charles Cotrena, Laura Damiani Branco, Rochele Paz Fonseca

\begin{abstract}
Introduction: Decision making (DM) is among the most important abilities for everyday functioning. However, the most widely used measures of DM come from behavioral paradigms, whose ecological validity and standalone use has been criticized in the literature. Though these issues could be addressed by the use of DM questionnaires as a complementary assessment method, no such instruments have been validated for use in Brazilian Portuguese. Therefore, the aim of this study was to conduct the translation and validation of the Melbourne Decision Making Questionnaire (MDMQ) for use in a Brazilian population. Methods: The adaptation of the MDMQ involved the following steps: translation, back-translation, expert review and pilot study. These steps were followed by factor analysis and internal consistency measurements, which led to the exclusion of 4 items from the scale. The 18-item version of the MDMQ was then administered to a validation sample consisting of healthy adults, as well as patients with bipolar disorder (BD) and major depressive disorder (MDD).

Results: The instrument displayed good internal consistency, with the hypervigilance subscale showing the lowest, though still acceptable, Cronbach's alpha value. Its factor structure was comparable to that of the original MDMQ according to confirmatory factor analysis. Nevertheless, the MDMQ was sensitive to both depression severity and the presence of MDD and BD, both of which are known to have an impact on DM ability.

Conclusion: The version of the MDMQ produced in the present study may be an important addition to neuropsychological assessment batteries with a focus on DM and related abilities Keywords: Decision making; surveys and questionnaires; psychometrics; neuropsychology.
\end{abstract}

\section{Resumo}

Introdução: A tomada de decisão (TD) é uma das habilidades mais relevantes para a funcionalidade. No entanto, esta habilidade é geralmente avaliada por meio de tarefas comportamentais, cuja validade ecológica tem sido questionada. De acordo com a literatura, a avaliação da TD deve ser complementada por questionários ou escalas, instrumentos estes que não estão disponíveis no português brasileiro. Desta forma, o objetivo deste estudo foi a tradução e validação de uma versão do Melbourne Decision Making Questionnaire (MDMQ), o instrumento mais amplamente utilizado na avaliação da TD, para uso em português.

Métodos: A adaptação da MDMQ foi realizada através da tradução, retrotradução, avaliação por painel de juízes e estudo piloto. A versão da escala produzida neste processo foi submetida a análise fatorial e avaliação de consistência interna, levando a exclusão de 4 itens da escala original. A versão resultante da MDMQ, contando com 18 itens no total, foi então utilizada em estudo de validação, em que a TD foi comparada entre adultos saudáveis e portadores de depressão e transtorno bipolar.

Resultados: $O$ instrumento demonstrou consistência interna satisfatória, apesar da obtenção de alfas de Cronbach relativamente baixos para a subescala de hipervigilância. A estrutura fatorial do questionário traduzido foi semelhante a observada no instrumento original. Todas as medidas derivadas da MDMQ, mostraram-se discriminativas na comparação entre adultos saudáveis e portadores de transtornos mentais.

Conclusão: A versão da MDMQ produzida neste estudo poderá realizar uma importante contribuição para a prática clínica e pesquisa neuropsicológica acerca da TD.

Descritores: Tomada de decisões; inquéritos e questionários; psicometria; neuropsicologia.

Programa de Pós-graduação em Psicologia, Pontifícia Universidade Católica do Rio Grande do Sul, Porto Alegre, RS, Brazil.

Submitted May 19 2017, accepted for publication Sep 142017.

Suggested citation: Cotrena C, Branco LD, Fonseca RP. Adaptation and validation of the Melbourne Decision Making Questionnaire to Brazilian Portuguese. Trends Psychiatry Psychother. 2018;40(1):29-37. http://dx.doi.org/10.1590/2237-6089-2017-0062 


\section{Introduction}

Decision making (DM) is among the most relevant constructs studied in cognitive neuroscience. It is a necessary ability for adequate functioning, and is often impaired in patients with psychiatric disorders such as schizophrenia, ${ }^{1}$ obsessive-compulsive disorder, ${ }^{2,3}$ bipolar disorder (BD) ${ }^{4}$ and depression, ${ }^{5}$ and neurological disorders such as multiple sclerosis ${ }^{6}$ and traumatic brain injury. ${ }^{7}$ Recent studies have also identified it as a significant predictor of clinical outcomes such as treatment dropout and relapse in substance disorders ${ }^{8,9}$ and future substance use in patients with BD. ${ }^{10}$ Given their ubiquitous presence across psychiatric conditions, DM impairments have been described by some authors as transdiagnostic markers of mental illness. ${ }^{11}$

However, DM difficulties can occur even in the absence of neuropsychiatric dysfunctions, ${ }^{12}$ and as such, efforts to prevent biases and improve DM ability have also extended to healthy adult populations. ${ }^{13}$ In healthy adults, DM has also been found to be a predictor of important clinical indicators such as heavy alcohol use, stress, well-being and depression symptoms. ${ }^{14,15}$

Most investigations of DM impairment, especially in psychiatric populations, rely on instruments designed for performance measurement, such as the Iowa Gambling Task (IGT), ${ }^{16}$ a computerized instrument which evaluates DM under uncertainty or risk in a simulated card game. This task has been used to study DM impairments in $\mathrm{BD}^{17}$ major depressive disorder (MDD) ${ }^{5}$ schizophrenia, ${ }^{1}$ and obsessive-compulsive disorder. ${ }^{18}$ Although these studies have made important contributions to the literature, additional measures of DM could complement these findings and perhaps address some of the limitations associated with the use of the IGT. These limitations include the difficulty identifying the cognitive processes underlying DM on the task, ${ }^{19}$ its sensitivity to context-specific factors such as mood, as well as methodological variability in terms of scoring methods and number of trials. ${ }^{20}$

One possible way to complement the study of DM in psychiatric, neurological and healthy populations could be the use of more ecological assessment tools such as questionnaires or scales. Such instruments have been identified as having greater clinical and ecological validity than many behavioral or experimental tasks in the neuropsychological literature. ${ }^{21} \mathrm{~A}$ recent review of DM questionnaires and scales identified the Melbourne Decision Making Questionnaire (MDMQ)22 as the most widely used instrument of its kind. ${ }^{23}$ The questionnaire is based on the conflict theory of DM proposed by Janis and Mann, ${ }^{24}$ and aimed to study this cognitive process within the social and affective context in which it is typically encountered. According to the conflict theory, any situation in which a decision must be made is a powerful source of intrapersonal stress due to its potential for material, financial or personal loss. The three main factors that determine the way people cope with this stress are: knowledge of the risks involved in each alternative, hope of finding superior alternatives and belief that there is sufficient time to select and ponder the consequences of alternatives available. Each combination of these factors results in a different style of DM. For instance, in an attempt to escape the stressful situation, individuals may uncritically adopt any alternative available, ignore important information about the risks involved in the process, or even avoid it altogether by procrastinating or passing on the responsibility to other individuals; these behavior patterns constitute the unconflicted adherence, unconflicted change and defensive avoidance strategies outlined by the theory. Alternatively, individuals may become hypervigilant, impulsively choosing a course of action in a desperate attempt to escape the stress of DM, or exercise a vigilant strategy, by weighing alternatives carefully and choosing an alternative in an adaptive and adequate manner.

The MDMQ therefore evaluates four different patterns of DM, namely, vigilance, hypervigilance, buckpassing and procrastination. Since its development, the MDMQ has been successfully used to examine the association between DM and personality, ${ }^{25-28}$ psychiatric disorders, $^{29}$ substance use, ${ }^{30-32}$ and symptoms of depression and anxiety. ${ }^{33}$ The MDMQ has been adapted from the original English into several other languages, including French, ${ }^{34}$ Italian, ${ }^{35}$ Spanish, ${ }^{36}$ Swedish, ${ }^{37}$ and Turkish, ${ }^{38,39}$ and proved to be a valuable addition to the literature in each of these languages. However, it has not yet been adapted into Brazilian Portuguese. Given the widespread use of the IGT in the Brazilian literature, ${ }^{40}$ and the unavailability of questionnaires and scales to complement this assessment, the adaptation of an instrument such as the MDMQ into Brazilian Portuguese would be a valuable addition to the existing literature.

As such, the aim of the present study was to conduct the translation and adaptation of the MDMQ into Brazilian Portuguese, and collect evidence of its validity and reliability by analyzing its factor structure, internal consistency, and sensitivity to external factors which are known to influence DM, such as the presence of psychiatric disorders (BD and MDD) and depression symptoms of varying levels of severity. 


\section{Method}

This study was conducted in two stages, consisting of the (1) adaptation process and (2) empirical validation of the MDMQ, respectively. Each of these stages involved a different set of participants and procedures, which will be described in the following sections.

\section{Adaptation of the MDMQ}

The adaptation of the MDMQ into Brazilian Portuguese was carried out in four steps. The first involved the independent translation of the original scale by two bilingual psychologists with expertise in neuropsychological assessment. This was followed by a creation of a consensus version of the scale in Portuguese based on the two translations. This instrument was then submitted to back translation from Portuguese to English, to determine the extent to which the translated items conveyed the original meaning of the items in the scale. Discrepancies identified in this process were rectified by a rewording of the Portuguese items. After these adjustments, the Portuguese version of the MDMQ was reviewed by a panel of four expert judges with experience in neuropsychological assessment. The judges were provided with information regarding the theoretical background of the scale, if necessary, and asked to identify which DM strategy was evaluated by each item in the instrument. All issues raised by the judges were addressed before submitting the scale to a pilot study in the fourth step of the adaptation process. An illustration of the stages involved in the adaptation of the MDMQ into Brazilian Portuguese is shown in Figure 1.

\section{Validation}

Upon completion of the adaptation process, the scale was administered to a larger sample in order to collect evidence of its validity and reliability. As a general rule, factor analysis studies tend to include 5 to 10 participants per observable variable, though simulation studies suggest that a minimum sample size of 200 may be required to conduct this type of analysis with sufficient statistical power. ${ }^{41}$ As such, the validation sample for the present study included a total of 234 participants. The sample consisted of healthy adults, as well as patients with MDD and BD. Patients were recruited from the mood disorders outpatient unit of a psychiatric hospital, a university teaching clinic,

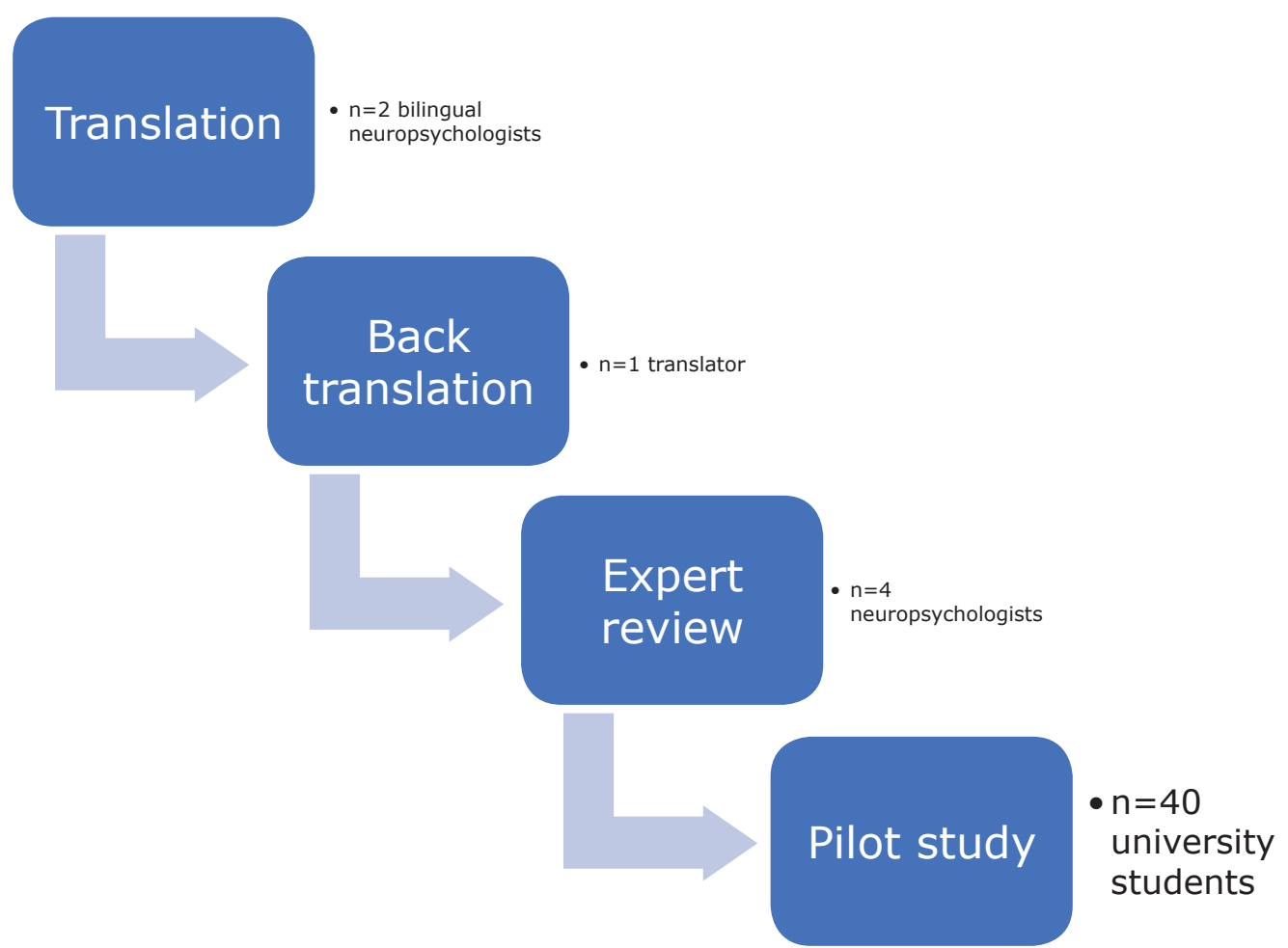

Figure 1 - Methodological procedures involved in the adaptation and validation of the Melbourne Decision Making Questionnaire into Brazilian Portuguese 
and private practice. Control participants were selected by convenience from work and university settings, as well as the community at large.

All patients were at least 18 years old, and had at least one year of formal education. The following exclusion criteria were applied to the sample: uncorrected sensory impairments which would interfere with task performance, neurological conditions, and pregnancy or lactation. Patients with psychotic symptoms at the time of testing or who reported substance abuse within the previous month were also excluded from participation. The control group was selected using the same criteria, and was screened for mood disorders according to DSM-5 criteria, cognitive impairment and intellectual disability.

\section{Instruments}

The MDMQ consists of 22 statements which describe attitudes toward DM or behaviors and thoughts that individuals may exhibit in such situations. For each of these 22 items, the respondent is asked to rate the extent to which these describe his behavior on a Likert scale ranging between 'True for me' (score 2), 'Sometimes true' (score 1) and 'Not true for me' (score 0 ). The MDMQ is composed of four subscales, each related to one of the DM styles described by Janis and Mann's conflict theory. ${ }^{24}$ The vigilance scale, the only one to tap into an adaptive DM style, is composed of six items that describe a thoughtful and cautious approach to DM (e.g., "When making decisions I like to collect a lot of information."). The procrastination subscale, composed of five items, contains statements such as" Even after I have made a decision I delay acting upon it." The buck-passing subscale contains six items in total, all referring to a tendency to shift responsibility onto other individuals during situations of DM (e.g., "I prefer that people who are better informed decide for me."). Both procrastination and buck-passing are considered avoidant styles of DM. The last subscale refers to hypervigilance, which leads the individual to seize impulsively and uncritically upon any alternative available in a desperate attempt to end the stress caused by the DM situation (e.g., "I cannot think straight if I have to make a decision in a hurry").

In addition to the MDMQ, participants in the validation study were assessed by means of questionnaires and screening instruments to identify and confirm inclusion and exclusion criteria. The Mini-Mental State Examination (MMSE) ${ }^{42,43}$ was used to screen for symptoms of dementia, while the Block Design and Vocabulary Subtests from the Wechsler Adult Intelligence Scales (WAIS-III) ${ }^{44}$ were used to exclude intellectual disability. Participants were also administered the Mini
International Neuropsychiatric Interview (MINI), ${ }^{45}$ and those with a diagnosis of MDD or BD completed the Hamilton Depression Rating Scale (HDRS) ${ }^{46,47}$ and the Young Mania Rating Scale (YMRS) 48,49 to evaluate current mood state.

\section{Data analysis}

Data were analyzed using both descriptive and inferential methods. Expert ratings in the adaptation stage of the instrument were interpreted based on percent agreement. The demographic and clinical characteristics of the validation sample were examined using mean and standard deviation (SD) values, as well as absolute frequencies and percentages, when applicable.

Theinternalstructure of the MDMQ was evaluatedusing confirmatory factor analysis (CFA) with weighted least squares means-variance (WLSMV) estimation. Model fit was determined using the root square mean error of approximation (RMSEA), as well as the comparative fit (CFI) and Tucker-Lewis indices (TLI). The cutoff values for model fit adopted in the present study were $>0.95$ for the CFI and TLI, and $<0.06$ for the RMSEA. ${ }^{50}$ These procedures were performed using the MPlus statistical software, version 6.12. Internal consistency analyses were performed using the Cronbach's alpha coefficient for the scale as a whole, as well as each of the subscales identified. Lastly, MDMQ scores were compared among participant groups in the validation sample using a two-way analysis of variance (ANOVA), with diagnosis (none vs. MDD vs. BD type I vs. type II) and depression severity (none vs. mild vs. moderate vs. severe) as between-subject factors.

\section{Results}

\section{Adaptation}

Upon completion of the translation and back translation stages of the adaptation process, the MDMQ was reviewed by a panel of experts to determine the extent to which each of the items captured their intended DM strategy. For 17 of the items, judgments of content validity were agreed upon by $100 \%$ of judges, whereas a $75 \%$ agreement rate was reached on further 3 items (items 2, 4, and 14), and a 50\% agreement rate was observed on item 8 ("I avoid making decisions."). Item 5 proved to be particularly problematic, and resulted in several concerns being raised by the judges who believed it did not adequately capture the theoretical construct of hypervigilance. As such, to ensure the content validity of this subscale, a new item, based on the definition of hypervigilance provided by Mann 
et al., ${ }^{22}$ was created and substituted for item 5 in the final version of the scale. The resulting version of the MDMQ was then pilot tested for comprehensibility in a sample of 40 university students with 18 to 50 years of age $(M=22.58 ; S D=6.96)$. All participants completed the scale successfully, and no comprehension or interpretation issues were identified on any of the items.

\section{Validation}

The clinical and demographic characteristics of each subgroup of participants in the validation sample is shown in Table 1.

In the first stage of the validation process, the factor structure of the Brazilian version of the MDMQ was analyzed using CFA to determine whether the scale conformed to a 4-factor model, as expected. Although all factor loadings were significant at $p<0.001$, the parameters for model fit did not meet the specified cutoff values. The CFA for the full, 22 -item scale yielded the following parameters: RMSEA $=0.095, \mathrm{CFI}=0.905$ and TLI $=0.892$.

The reliability of each subscale was then calculated using Cronbach's alpha. The results of this procedure identified two items which, if deleted, would increase the reliability of their respective subscales. These were items 15 and 16, from the buck-passing and vigilance subscales, respectively. A reassessment of model fit using CFA on the scale without these two items also failed to produce a satisfactory model (RMSEA $=0.160$, $\mathrm{CFI}=0.728$ and $\mathrm{TLI}=0.693$ ).

We then proceeded to evaluate the item-total correlations for the remaining 20 items in their respective subscales. This process revealed that all but two items, both in the hypervigilance subscales, had item-total correlations $>0.40$. Items 5 and 17 yielded item-total correlations of 0.315 and 0.374 , respectively. These two items were then removed, and the model fit of the remaining 18 items was reevaluated using CFA. This time, though the RMSEA was slightly above the cutoff value, both the CFI and TLI were found to be acceptable: $\mathrm{RMSEA}=0.069, \mathrm{CFI}=0.964$ and $\mathrm{TLI}=0.958$. All item loadings were significant at $p<0.001$. Though item 2 in the hypervigilance scale still had an itemtotal correlation slightly below 0.4 , its removal from the scale had a significant negative impact on model fit parameters. As such, all 18 items were retained in the final version of the scale.

The internal consistency of the scale as a whole was found to be $a=0.824$, while corresponding values for each of the subscales were as follows: $a=0.857$ for vigilance, $a=0.853$ for buck-passing, $a=0.664$ for hypervigilance and $a=0.791$ for procrastination. The final items in the MDMQ are shown in Table 2.

After the psychometric properties of the scale and its final format were defined, total scores were calculated for each subscale by adding up the ratings of the relevant items. The correlations between factor scores were then calculated. The results of this analysis are shown in Table 3.

As can be seen in the table, significant positive correlations were identified between all three maladaptive styles of DM. Adaptive decision-making, on the other hand, showed a significant negative correlation with procrastination and buck-passing, and so significant association with hypervigilance.

Total values for each subscale scores were also compared between groups in the validation sample in a two-way ANOVA, with diagnosis and mood state as between-subject factors. Scores on the vigilance scale displayed a significant main effect of diagnosis $\left(F_{3,226}=3.150, \mathrm{p}=0.026, \mathrm{\eta}_{\mathrm{p}}{ }^{2}=0.042\right)$. Post-

Table 1 - Demographic and clinical characteristics of each participant group

\begin{tabular}{lcccc}
\hline & $\begin{array}{c}\text { Control } \\
(\mathbf{n = 1 0 1})\end{array}$ & $\begin{array}{c}\text { MDD } \\
(\mathbf{n = 6 0 )}\end{array}$ & $\begin{array}{c}\text { BD type II } \\
(\mathbf{n = 3 7})\end{array}$ & $\begin{array}{c}\text { BD type I } \\
(\mathbf{n = 3 6 )}\end{array}$ \\
\hline Age & $28.67(11.22)$ & $37.57(13.89)$ & $41.74(14.83)$ & $44.05(12.02)$ \\
Education ${ }^{+}$ & $15.40(3.71)$ & $14.95(4.56)$ & $15.56(5.02)$ & $12.42(5.90)$ \\
SES & $30.62(7.08)$ & $30.11(7.62)$ & $31.31(8.38)$ & $25.17(8.57)$ \\
FRW & $18.50(4.27)$ & $16.51(5.44)$ & $16.13(4.86)$ & $12.08(5.83)$ \\
HDRS & $1.70(2.03)$ & $9.70(7.82)$ & $13.23(10.02)$ & $14.25(9.64)$ \\
YMRS & $0.75(1.50)$ & $1.49(1.89)$ & $3.53(10.02)$ & $2.28(3.87)$ \\
IQ & $120.46(11.33)$ & $117.58(11.72)$ & $112.12(10.53)$ & $103.38(11.17)$ \\
Gender $(\mathrm{F} ; \mathrm{n})^{*}$ & $46(45.5 \%)$ & $42(60.0 \%)$ & $28(75.7 \%)$ & $31(86.1 \%)$ \\
\hline
\end{tabular}

Data presented as mean and standard deviation, unless otherwise specified.

$\mathrm{BD}=$ bipolar disorder; FRW = frequency of reading and writing; HDRS = Hamilton Depression Rating Scale; IQ = intelligence quotient; MDD = major depressive disorder; MMSE = Mini-Mental State Examination; SES = socioeconomic status; YMRS = Young Mania Rating Scale.

* Absolute and relative frequency of female participants.

+ Years of formal education. 
hoc tests revealed that control participants $(M=15.63$; $\mathrm{SD}=3.07)$ scored higher than participants with $\mathrm{BD}$ type I $(M=11.94 ; S D=5.34, p<0.001)$ and $B D$ type II $(M=13.71 ; S D=4.52, p=0.045)$.

Scores on the hypervigilance scale displayed a significant main effect of mood state $\left(F_{3,226}=4.377\right.$, $\left.\mathrm{p}=0.005, \eta_{\mathrm{p}}{ }^{2}=0.058\right)$. Post-hoc tests revealed that participants with no symptoms of depression $(M=5.64$; $\mathrm{SD}=2.71$ ) obtained lower scores on this subscale than those with either mild $(M=7.52 ; S D=2.54, p=0.023)$ or moderate $(M=8.79 ; S D=1.84, p<0.001)$ symptoms of depression.

The procrastination subscale also displayed a main effect of mood state $\left(F_{3,226}=3.577, \mathrm{p}=0.015, \eta_{\mathrm{p}}{ }^{2}=0.048\right)$.
Post-hoc tests revealed that participants with no symptoms of depression ( $M=7.45 ; \mathrm{SD}=3.88)$ as well as those with mild symptoms $(M=9.02 ; S D=4.31)$ obtained lower scores on this subscale than those with moderate symptoms of depression ( $M=11.95 ; S D=2.90), p=0.001$ and $p=0.051$, respectively. The main effect of participant diagnosis on the procrastination subscale also approached significance $\left(F_{3,226}=2.598, \mathrm{p}=0.053, \eta_{\mathrm{p}}^{2}=0.035\right)$, and as such, post-hoc tests for participant subgroups were also conducted. These procedures revealed that control participants $(M=6.78 ; S D=3.60)$ scored lower that subjects with $M D D(M=8.75 ; S D=4.07, p=0.052), B D$ type II $(M=9.24 ; S D=4.71, p=0.002)$ and $B D$ type I $(M=9.92 ; S D=3.88, p<0.001)$ on this subscale.

Table 2 - Final translation of items in the Melbourne Decision Making Questionnaire

\begin{tabular}{|c|c|c|}
\hline Original version & Final version & Decisional style \\
\hline $\begin{array}{l}\text { 1. When making decisions I like to collect a lot of } \\
\text { information. }\end{array}$ & $\begin{array}{l}\text { Quando tomo uma decisão, eu gosto de reunir uma } \\
\text { quantidade de informações. }\end{array}$ & Vigilance \\
\hline $\begin{array}{l}\text { 2. After a decision is made I spend a lot of time } \\
\text { convincing myself it was correct. }\end{array}$ & $\begin{array}{l}\text { Depois de tomar uma decisão, passo bastante tempo me } \\
\text { convencendo que fiz a escolha certa. }\end{array}$ & Hypervigilance \\
\hline 3. I put off making decisions. & Eu adio minhas decisões sobre as coisas. & Procrastination \\
\hline 4. I do not make decisions unless I really have to. & Eu não tomo decisões a não ser que seja realmente preciso. & Buck-passing \\
\hline $\begin{array}{l}\text { 5. Even after I have made a decision I delay } \\
\text { acting upon it. }\end{array}$ & $\begin{array}{l}\text { Mesmo após ter me decidido, demoro para agir conforme } \\
\text { minha decisão }\end{array}$ & Procrastination \\
\hline 6. I prefer to leave decisions to others. & Eu prefiro deixar que os outros decidam por mim. & Buck-passing \\
\hline 7. I avoid making decisions. & Eu evito tomar decisões, porque para mim é difícil resolver. & Buck-passing \\
\hline 8. I take a lot of care before choosing. & Eu tenho bastante cuidado antes de tomar uma decisão. & Vigilance \\
\hline $\begin{array}{l}\text { 9. When I have to make a decision I wait a long } \\
\text { time before starting to think about it. }\end{array}$ & $\begin{array}{l}\text { Quando eu preciso tomar alguma decisão, espero bastante } \\
\text { tempo antes de pensar sobre ela. }\end{array}$ & Procrastination \\
\hline $\begin{array}{l}\text { 10. I cannot think straight if I have to make a } \\
\text { decision in a hurry. }\end{array}$ & $\begin{array}{l}\text { Não consigo pensar direito quando preciso tomar uma decisão } \\
\text { com pressa. }\end{array}$ & Hypervigilance \\
\hline $\begin{array}{l}\text { 11. I prefer that people who are better informed } \\
\text { decide for me. }\end{array}$ & $\begin{array}{l}\text { Eu prefiro que pessoas que estejam mais informadas tomem } \\
\text { as decisões por mim. }\end{array}$ & Buck-passing \\
\hline 12. I consider how best to carry out a decision. & $\begin{array}{l}\text { Eu levo em consideração qual a melhor maneira de fazer a } \\
\text { decisão. }\end{array}$ & Vigilance \\
\hline $\begin{array}{l}\text { 13. I waste a lot of time on trivial matters before } \\
\text { getting to the final decision. }\end{array}$ & $\begin{array}{l}\text { Eu perco bastante tempo com coisas de menos importância } \\
\text { antes de chegar a uma decisão final. }\end{array}$ & Procrastination \\
\hline 14. I like to consider all of the alternatives. & Gosto de pensar em todas as alternativas. & Vigilance \\
\hline 15. I delay making decisions until it is too late. & Eu espero para tomar decisões até que seja tarde demais. & Procrastination \\
\hline $\begin{array}{l}\text { 16. If a decision can be made by me or another } \\
\text { person I let the other person make it. }\end{array}$ & $\begin{array}{l}\text { Se uma decisão pode ser feita por mim ou por outra pessoa, } \\
\text { deixo a outra pessoa decidir. }\end{array}$ & Buck-passing \\
\hline $\begin{array}{l}\text { 17. I try to be clear about my objectives before } \\
\text { choosing. }\end{array}$ & $\begin{array}{l}\text { Eu gosto de ter objetivos bem claros antes de tomar uma } \\
\text { decisão. }\end{array}$ & Vigilance \\
\hline $\begin{array}{l}\text { 18. I feel as if I am under tremendous time } \\
\text { pressure when making decisions. }\end{array}$ & $\begin{array}{l}\text { Me sinto como se estivesse sob muita pressão de tempo } \\
\text { quando tomo decisões. }\end{array}$ & Hypervigilance \\
\hline
\end{tabular}

Table 3 - Correlations between subscales of the 18-item Melbourne Decision Making Questionnaire

\begin{tabular}{llccl}
\hline & & 1 & 2 & 3 \\
\hline 1. & Vigilance & - & - & - \\
2. Hypervigilance & -0.015 & - & - \\
3. Procrastination & $-0.246^{*}$ & $0.560^{*}$ & $0.640 *$ \\
4. Buck-passing & $-0.246^{*}$ & $0.540^{*}$ & 0.64 \\
\hline
\end{tabular}

$* p<0.001$. 
Lastly, the buck-passing scale reflected main effects of both diagnosis $\left(F_{3,226}=3.809, \mathrm{p}=0.011, \eta_{\mathrm{p}}^{2}=0.051\right)$ and mood state $\left(F_{3,226}=3.808, \mathrm{p}=0.041, \eta_{\mathrm{p}}{ }^{2}=0.038\right)$. Post-hoc tests revealed that participants with BD type I $(M=9.76 ; S D=5.17)$ obtained higher scores on this subscale than both the control subjects $(M=5.39$; $\mathrm{SD}=3.97, \mathrm{p}<0.001)$ and participants with MDD $(M=7.13 ; S D=4.30, p=0.022)$. A significant difference was also observed between the scores obtained by control subjects and those with $B D$ type II $(M=8.26$; $S D=5.44$ ) on this subscale, $p=0.002$. Post-hoc tests for mood state revealed that individuals with no symptoms of depression $(M=5.90 ; S D=3.96)$ obtained lower scores on this subscale than those with mild $(M=8.89$; $S D=5.31, p=0.023)$ or moderate $(M=9.79 ; S D=4.55$, $\mathrm{p}=0.020$ ) depression.

\section{Discussion}

The aim of the present study was to adapt the MDMQ to Brazilian Portuguese, and collect evidence of its validity and reliability by analyzing its factor structure, internal consistency, and sensitivity to external factors which are known to influence DM. Throughout the adaptation process, measures were taken to preserve both the semantic qualities of the original items as well as their relationship to the DM styles they were each meant to represent. Linguistic equivalence was ensured by involving both translation and back-translation methods, and the content validity of each item was investigated by a group of expert judges with experience in DM assessment. The ability of the translated instrument to evaluate the DM strategies proposed by Mann et al. ${ }^{22}$ was corroborated by both the factor analysis procedure and the results of the comparative study. The factor structure of the translated instrument was comparable to that of the original MDMQ according to CFA. The instrument as a whole, as well as most of its subscales, displayed good internal consistency. The hypervigilance subscale showed the lowest, though still acceptable, Cronbach's alpha value. Lastly, the MDMQ was sensitive to both depression severity and the presence of MDD and $B D$, both of which are known to have an impact on DM ability.

Findings regarding the high prevalence of maladaptive DM strategies relative to adaptive DM in patients with mood disorders corroborate those obtained by Radford et al. ${ }^{29}$ Participants with both BD type I and BD type II obtained lower scores on the vigilance scale than control participants, corroborating the current literature regarding the presence of DM impairments in both of these disorders. ${ }^{17,51}$ The presence of higher procrastination scores among patients with BD and control subjects is also in agreement with the literature, which has cited procrastination difficulties as a major cause of clinical distress among patients with this condition. ${ }^{52,53}$ The fact that both BD type I and BD type II differed from control participants on the buck-passing scale is also an important finding. Conflict theory defines buck-passing as an avoidant DM strategy, in which the decision-maker shifts responsibility to someone else in order to escape or avoid the stress associated with DM. ${ }^{22}$ Though avoidant coping styles are usually associated with $M D D,{ }^{54}$ they have also been found to be highly prevalent in individuals with BD. ${ }^{55}$

The MDMQ was also sensitive to differences in depression severity in the sample. Interestingly, participant scores on all three maladaptive DM subscales differed between control subjects and individuals with mild symptoms of depression. This finding corroborates previous literature, in which even subclinical symptoms of depression have been found to influence DM in patients with a history of depressive episodes. ${ }^{56}$ Given that difficulties in DM are considered a diagnostic criterion for a MDD episode together with other cognitive impairments, ${ }^{57}$ the fact that the Brazilian version of the MDMQ was able to identify differences between asymptomatic individuals and those with varying levels of depression provides important evidence of its criterion-related validity.

Although the primary goal of the present study was to collect evidence of the validity of the MDMQ, the present findings also speak to its potential applicability to clinical settings. In addition to complementing the assessment of DM using behavioral tasks, the MDMQ provides several advantages over existing instruments with regard to the assessment and management of impairments in DM ability. Unlike instruments such as the IGT, which can be used to categorize DM as impaired or unimpaired but provide little indication as to the processes associated with any difficulties identified, the MDMQ identifies specific profiles of maladaptive DM. The behaviors described in the questionnaire reflect the patient's daily functioning and shed light on the coping styles used by the individual in response to stressful situations. The results provided by the MDMQ can therefore be used to target clinical interventions and comprehend the association between the patient's symptoms and cognitive or behavioral traits. A person's responses to the MDMQ, and scores on each subscale of maladaptive DM according to the conflict theory, may help clinicians identify dysfunctional behaviors or coping strategies. The conflict theory of DM has already been successfully integrated into intervention strategies in English-speaking countries, ${ }^{58}$ and as such, the development of a theoretically-sound version of 
the MDMQ in Brazilian Portuguese may contribute to treatment strategies in the local population. The MDMQ is also a paper-and-pencil instrument, which does not require any special equipment for administration or scoring, and can be easily used across different clinical and research settings.

The present findings must be interpreted in light of some limitations. These include the fact that the backtranslation procedure was conducted only once, and did not involve a consensus between multiple translators, and the low reliability of the hypervigilance scale. However, it is important to note that the hypervigilance scale was also identified as having the lowest Cronbach's alpha coefficient of all MDMQ subscales at the time of its development, ${ }^{22}$ and that the value obtained in the present study was similar to that observed in other investigations of the psychometric properties of the MDMQ. ${ }^{26}$

Nevertheless, the present study produced a reliable and valid version of the MDMQ in Brazilian Portuguese. To date, this may be the only standardized questionnaire in Brazilian Portuguese which allows for the assessment of this particular cognitive skill. This instrument will hopefully contribute to the existing literature on both the neuropsychology and cognitive underpinnings of different psychiatric and neurological disorders, and make for an important complementation of existing findings using behavioral instruments such as the IGT.

\section{Acknowledgments}

Charles Cotrena and Laura Damiani Branco received financial support from the government agencies Coordenação de Aperfeiçoamento de Pessoal de Nível Superior (CAPES) and Conselho Nacional de Desenvolvimento Científico e Tecnológico (CNPq), respectively. These institutions were not involved in any stage of the study design, data collection or manuscript drafting, and had no association with the study itself save for the financial support provided to the authors.

\section{Disclosure}

No conflicts of interest declared concerning the publication of this article.

\section{References}

1. Matsuzawa D, Shirayama $Y$, Niitsu T, Hashimoto K, Iyo M. Deficits in emotion based decision-making in schizophrenia: a new insight based on the Iowa Gambling Task. Prog Neuropsychopharmacol Biol Psychiatry. 2015;57:52-9.
2. Dittrich $\mathbf{W H}$, Johansen T. Cognitive deficits of executive functions and decision-making in obsessive-compulsive disorder. Scand J Psychol. 2013;54:393-400.

3. Grassi G, Pallanti S, Righi L, Figee M, Mantione M, Denys D, et al. Think twice: Impulsivity and decision making in obsessivecompulsive disorder. J Behav Addict. 2015;4:263-72.

4. Martino DJ, Strejilevich SA, Torralva T, Manes F. Decision making in euthymic bipolar I and bipolar $\{$ II $\}$ disorders. Psychol Med. 2011;41:1319-27.

5. Must A, Horvath S, Nemeth VL, Janka Z. The Iowa Gambling Task in depression - what have we learned about sub-optimal decision-making strategies? Front Psychol. 2013;4:732.

6. Sepulveda M, Fernandez-Diez B, Martinez-Lapiscina EH, Llufriu S, Sola-Valls N, Zubizarreta I, et al. Impairment of decision-making in multiple sclerosis: A neuroeconomic approach. Mult Scler. 2016 Nov 1:1352458516682103. doi: 10.1177/1352458516682103. [Epub ahead of print]

7. Cotrena C, Branco LD, Zimmermann N, Cardoso CO, GrassiOliveira R, Fonseca RP. Impaired decision-making after traumatic brain injury: The Iowa Gambling Task. Brain Inj. 2014;28:1070-5.

8. Stevens $L$, Betanzos-Espinosa P, Crunelle $C L$, Vergara-Moragues E, Roeyers H, Lozano O, et al. Disadvantageous decision-making as a predictor of drop-out among cocaine-dependent individuals in long-term residential treatment. Front Psychiatry. 2013;4:149.

9. Stevens L, Goudriaan AE, Verdejo-Garcia A, Dom G, Roeyers H, Vanderplasschen $W$. Impulsive choice predicts short-term relapse in substance-dependent individuals attending an in-patient detoxification programme. Psychol Med. 2015;45:2083-93.

10. Nejtek VA, Kaiser KA, Zhang B, Djokovic M. Iowa Gambling Task scores predict future drug use in bipolar disorder outpatients with stimulant dependence. Psychiatry Res. 2013;210:871-9.

11. Goschke T. Dysfunctions of decision-making and cognitive control as transdiagnostic mechanisms of mental disorders: advances, gaps, and needs in current research. Int J Methods Psychiatr Res. 2014;23:41-57.

12. Bull PN, Tippett LJ, Addis DR. Decision making in healthy participants on the Iowa Gambling Task: new insights from an operant approach. Front Psychol. 2015;6.

13. Leddy MA, Anderson BL, Schulkin J. Cognitive-behavioral therapy and decision science. New Ideas Psychol. 2013;31:173-83.

14. Goudriaan AE, Grekin ER, Sher KJ. Decision making and response inhibition as predictors of heavy alcohol use: a prospective study. Alcohol Clin Exp Res. 2011;35:1050-7.

15. Bavolar J, Orosova O. Decision-making styles and their associations with decision-making competencies and mental health. Judgm Decis Mak. 2015;10:115-22.

16. Bechara A. Iowa gambling task: professional manual. Lutz: Psychological Assessment Resources, Inc.; 2007.

17. Adida M, Jollant F, Clark L, Besnier N, Guillaume S, Kaladjian A, et al. Trait-related decision-making impairment in the three phases of bipolar disorder. Biol Psychiatry. 2011;70:357-65.

18. Zhang L, Dong Y, Ji Y, Zhu C, Yu F, Ma H, et al. Dissociation of decision making under ambiguity and decision making under risk: A neurocognitive endophenotype candidate for obsessivecompulsive disorder. Prog Neuro-Psychopharmacology Biol Psychiatry. 2015;57:60-8.

19. Stocco A, Fum D, Napoli A. Dissociable processes underlying decisions in the Iowa Gambling Task: a new integrative framework. Behav Brain Funct. 2009;5:1.

20. Okdie BM, Buelow MT, Bevelhymer-Rangel K. It's all in how you think about it: construal level and the Iowa Gambling Task. Front Neurosci. 2016;10:2.

21. Isquith PK, Roth RM, Gioia G. Contribution of rating scales to the assessment of executive functions. Appl Neuropsychol Child. 2013;2:125-32.

22. Mann L, Burnett $P$, Radford M, Ford S. The Melbourne Decision Making Questionnaire: an instrument for measuring patterns for coping with decisional conflict. J Behav Decis Mak. 1997;10:1-19.

23. Branco LD, Cotrena C, Cardoso CO, Fonseca RP. Avaliação da tomada de decisão utilizando questionários: revisão sistemática da literatura. Aval Psicol. 2014;13:67-76.

24. Janis IL, Mann L. Decision making: A psychological analysis of conflict, choice, and commitment. New York: Free Press; 1977. $488 \mathrm{p}$.

25. Deniz M. An investigation of decision making styles and the fivefactor personality traits with respect to attachment styles. Educ Sci Theory Pract. 2011;11:105-13.

26. Bouckenooghe D, Vanderheyden $K$, Mestdagh S, van Laethem S. Cognitive motivation correlates of coping style in decisional conflict. J Psychol. 2007;141:605-26. 
27. Fabio A Di. Decisional procrastination correlates: personality traits, self-esteem or perception of cognitive failure? Int J Educ Vocat Guid. 2006;6:109-22.

28. Halama $P$, Gurńáková J. Need for structure and Big Five personality traits as predictors of decision making styles in health professionals. Stud Psychol (Bratisl). 2014;56:171-9.

29. Radford MH, Mann L, Kalucy RS. Psychiatric disturbance and decision-making. Aust N Z J Psychiatry. 1986;20:210-7.

30. Gorodetzky H, Sahakian BJ, Robbins TW, Ersche KD. Differences in self-reported decision-making styles in stimulant-dependent and opiate-dependent individuals. Psychiatry Res. 2011;186:437-40.

31. Phillips JG, Ogeil RP. Cannabis, alcohol use, psychological distress, and decision-making style. J Clin Exp Neuropsychol. 2017;39:670-81.

32. Phillips JG, Ogeil RP. Decisional styles and risk of problem drinking or gambling. Pers Individ Dif. 2011;51:521-6.

33. Umeh K, Omari-Asor L. Emotional vulnerability and coping styles for resolving decisional conflict. J Psychol. 2011;145:297-312.

34. Bailly N, Ilharragorry-Devaux M-L. Adaptation et validation en langue Française d'une échelle de prise de décision. Can J Behav Sci. 2011;43:143-9.

35. Nota L, Soresi S. Adattamento italiano del Melbourne Decision Making Questionnaire [Italian adaptation of the Melbourne Decision Making Questionnaire]. GIPO G Ital di Psicol dell'Orientamento. 2000;3:38-52.

36. Sáez de Heredia RA, Laca Arocena F, Valencia Gárate J. Decisionmaking patterns, conflict sytles, and self-esteem. Psicothema. 2004;16:110-6.

37. Isaksson $U$, Hajdarević $S$, Jutterström L, Hörnsten $\AA$. Validity and reliability testing of the Swedish version of Melbourne Decision Making Questionnaire. Scand J Caring Sci. 2014;28:405-12.

38. Deniz ME. Investıgatıon of the relatıon between decısın makıng self-esteem, decısıon makıng style and problem solvıng skills of university students. Eurasian J Educ Res. 2004;15:23-35.

39. Oguzhan C, M ED. Study on the validity and reliability of Melbourne Decision Making Scale in Turkey. Educ Res Rev. 2015;10:1434-41.

40. Areias G, Paixão R, Figueira APC. O Iowa Gambling Task: uma revisão crítica. Psicol Teor Pesqui. 2013;29:201-10.

41. Myers ND, Ahn S, Jin Y. Sample size and power estimates for a confirmatory factor analytic model in exercise and sport: A Monte Carlo approach. Res Q Exerc Sport. 2011;82:412-23.

42. Folstein MF, Folstein SE, McHugh PR. Mini-Mental State: a practical method for grading the cognitive state of patients for the clinician. J Psychiatr Res. 1975;12:189-98.

43. Chaves MLF, Izquierdo I. Differential diagnosis between dementia and depression: a study of efficiency increment. Acta Neurol Scand. 1992;85:378-382.

44. Nascimento E. WAIS-III: Escala de inteligência Wechsler para adultos. São Paulo: Casa do Psicólogo; 2004.

45. Amorim P. Mini International Neuropsychiatric Interview (MINI): validation of a short structured diagnostic psychiatric interview. Rev Bras Psiquiatr. 2000;22:103-15.
46. Hamilton M. A rating scale for depression. J Neurol Neurosurg Psychiatry. 1960;23:56-62

47. Gorenstein C, Andrade LHSG, Zuardi AW. Escalas de avaliação clínica em psiquiatria e psicofarmacologia. São Paulo: Lemos Editorial; 2000.

48. Young RC, Biggs JT, Ziegler VE, Meyer DA. A rating scale for mania: Reliability, validity and sensitivity. Br J Psychiatry. 1978;133:42935.

49. Vilela ], Loureiro S. Escala de avaliação de mania de young estudo das qualidades psicométricas da versão brasileira. In: Gorenstein C, Andrade CL, Zuardi AW, editors. Escalas de Avaliação Clínica em Psiquiatria e Psicofarmacologia. São Paulo: Lemos Editorial; 2000. p. 113-24.

50. Hu L, Bentler PM. Fit indices in covariance structure modeling: Sensitivity to underparameterized model misspecification. Psychol Methods. 1998;3:424-53.

51. Cotrena C, Branco LD, Shansis FM, Fonseca RP. Executive function impairments in depression and bipolar disorder: association with functional impairment and quality of life. J Affect Disord. 2016;190:744-53.

52. Todd NJ, Jones SH, Lobban FA. What do service users with bipolar disorder want from a web-based self-management intervention? A qualitative focus group study. Clin Psychol Psychother. 2013;20:531-43.

53. Gudmundsson E. The bipolar II disorder personality traits, a true syndrome? J Affect Disord. 2015;178:107-11.

54. Ottenbreit ND, Dobson KS, Quigley L. An examination of avoidance in major depression in comparison to social anxiety disorder. Behav Res Ther. 2014;56:82-90.

55. Fortgang RG, Hultman CM, Cannon TD. Coping styles in twins discordant for schizophrenia, bipolar disorder, and depression. Clin Psychol Sci. 2016;4:216-28.

56. Yang $X$ hua, Huang J, Zhu $C$ ying, Wang $Y$ fei, Cheung EFC, Chan RCK, et al. Motivational deficits in effort-based decision making in individuals with subsyndromal depression, first-episode and remitted depression patients. Psychiatry Res. 2014;220:874-82.

57. American Psychiatric Association. Diagnostic and statistical manual of mental disorders. 5th Ed. Washington: American Psychiatric Association; 2013.

58. Hollen PJ, Gralla RJ, Jones RA, Thomas CY, Brenin DR, Weiss GR, et al. A theory-based decision aid for patients with cancer: results of feasibility and acceptability testing of DecisionKEYS for cancer. Support Care Cancer. 2013;21:889-99.

\section{Correspondence:}

Laura Damiani Branco

Av. Ipiranga, 6681, Prédio 11, Sala 32

90619-900 - Porto Alegre, RS - Brazil

Tel./fax: +55 (51) 33203500, ext. 7742

E-mail: lauradbranco@gmail.com 